\title{
Relationship between Corky Root Disease and Yield of Crisphead Lettuce
}

\author{
L.E. Datnoff ${ }^{1}$ and R.T. Nagata ${ }^{2}$ \\ Everglades Research and Education Center, University of Florida, Belle Glade, FL 33430 \\ Additional index words. yield losses, Rhizomonas suberifaciens, Lactuca sativa
}

\begin{abstract}
The effects of corky root (CR) disease, caused by Rhizomonas suberifaciens(van Bruggen, Jochimsen, and Brown) on fresh and marketable weights of lettuce (Lactuca sativa $L$.) were assessed during the 1988 and 1989 cropping seasons in several commercial lettuce fields. The resistant crisphead cultivars Raleigh and South Bay and the susceptible cultivars Ithaca and Shawnee produced similar yields in fields either planted in lettuce for the first time or in continuous lettuce production for three cropping cycles. Average yields of the resistant cultivars, from two fields cropped for six cycles naturally infested with CR, ranged from 875 to $1062 \mathrm{~g} / \mathrm{head}$ fresh weight and 674 to $907 \mathrm{~g} /$ head marketable weight. The average yields of the susceptible cultivars in these infested fields ranged from 419.8 to $668.7 \mathrm{~g} / \mathrm{head}$ fresh weight ( $37 \%$ to $52 \%$ yield loss) and 317.5 to $488.2 \mathrm{~g} / \mathrm{head}$ marketable weight $(46 \%$ to $53 \%$ yield loss). CR severity ratings were highly negatively correlated with root dry matter accumulation and whole and marketable head weights of-lettuce.
\end{abstract}

$\mathrm{CR}$ is a serious disease of lettuce. It has been reported from various North American production areas and Italy (Busch and Barron, 1963; Datnoff and Nagata, 1990; D’Ercole, 1981; van Bruggen et al., 1989). For many years, the etiology of this soilborne disease was controversial, and its presence was attributed to numerous abiotic and biotic causes (Brown and Michelmore, 1988; Busch and Barron, 1963; Guzman, 1984; van Bruggen et al., 1988). In 1984, a slow-growing bacterium was isolated (Waters and Grogan, 1984), and van Bruggen et al. (1988) demonstrated that this bacterium was' the causal agent of the disease. Subsequently, the name Rhizomonas suberifaciens gen. nov., sp. nov. (van Bruggen et al., 1990b) was proposed for this gram-negative bacterium.

A paucity of information presently exists about the biology and epidemiology of this pathogen, since a reliable selective medium for isolating this organism is not available. In addition, effective control strategies have primarily focused on fumigants or host resistance. Since fumigants are cost prohibitive, host resistance currently represents the best management strategy. Brown and Michelmore (1988) demonstrated that resistance is conferred by a single recessive gene.

In Florida, CR has been observed since the early 1970s. A breeding program was initiated in 1976 to develop CR-resistant lettuce cultivars (Guzman, 1981). Subsequently, five commercial cultivars with resistance or tolerance to CR have been released, including three crisphead and two romaine lettuce types (Guzman, 1984, 1986; Guzman et al., 1990). Recently, two buttercrisp types with resistance to CR have been released (R.T.N., V.L. Guzman, L. E. D., R.N. Raid, unpublished). CRresistant cultivars have replaced the susceptible types in commercial lettuce production in Florida.

Symptoms of CR appear initially as yellow lesions or bands on the taproot. As the disease progresses, the taproot becomes corked and brittle (van Bruggen et al., 1989). Tap and lateral root development in infected plants are severely reduced, and

Received for publication 19 Feb. 1991. Accepted for publication 10 Sept. 1991 Florida Agricultural Experiment Station, Journal Series no. R-01644. We thank South Bay Growers for their assistance in conducting these field studies, and M. Robins and V. Johnson for their excellent technical assistance. The cost of publishing this paper was defrayed in part by the payment of page charges. Under postal regulations, this paper therefore must be hereby marked advertisement solely to indicate this fact.

'Assistant Professor of Plant Pathology.

Assistant Professor of Horticulture. heads are often unmarketable. Despite the seriousness of this disease, we found no quantitative information on its impact on yield. The objectives of this study were to estimate quantitatively CR root disease severity and to relate disease severity to yield of crisphead lettuce grown in naturally infested organic soils.

\section{Materials and Methods}

Experiments were conducted during Fall 1988 and 1989, and Spring 1989. Several commercial lettuce fields in the Everglades Agricultural Area of south Florida were selected, based on previous cropping histories, to assess the effects of CR on fresh and marketable head weights. Locations A and B had been cropped continuously with lettuce for the past 6 years, and CR severity was high on the sixth crop. Location $\mathrm{C}$ was cropped with lettuce for 3 years, and CR levels were moderate. Locations D and E had been planted to sugarcane for the past 20 years and never planted to lettuce. Fields were fertilized according to soil test recommendations, and preplant fertilizer applications were disked into the soil before planting. Experiments were performed on soils classified as a Pahokee Muck (euic, hyperthermic Lithic Medisaprist). The soil $\mathrm{pH}$ from Locations A-E ranged from 5.4 to 7.5. CR-resistant crisphead lettuce cultivar Raleigh and South Bay and the susceptible cultivars Ithaca and Shawnee were direct-seeded in a randomized ecrmplete-block design with eight replications. Experimental units consisted of a $6.1-\mathrm{m}$ section of elevated double row beds on $0.9-\mathrm{m}$ centers for each cultivar. Lettuce was thinned at the four-leaf stage to provide a $0.3-\mathrm{m}$ in-row spacing. Total and above-ground fresh and marketable weights of crisphead lettuce were recorded at crop maturity, $\approx 65$ to 70 days after sowing. Ten heads of lettuce and roots were randomly harvested from each experimental unit. Marketable weight was (head weight - wrapper leaves). The percent reduction in yield was determined by averaging the mean yield of the two resistant and two susceptible cultivars and calculating the loss using the following formula: Yield reduction $(\%)=($ mean yield of resistant cultivars - mean yield of susceptible cultivars)/mean yield of resistant cultivars) $\times 100$ (Pataky and Lim, 1981).

CR severity ratings were recorded on the day of harvest using a modified Brown and Michelmore scale (Brown and Michel-

$\overline{\text { Abbreviation: }} \mathrm{CR}$, corky root. 
Table 1. ANOVA and contrast estimates of location and cultivar effects on fresh and marketable head weights, CR severity, and tap and lateral root dry weights.

\begin{tabular}{|c|c|c|c|c|c|c|}
\hline \multirow[b]{3}{*}{ Source } & \multirow[b]{3}{*}{ df } & \multicolumn{5}{|c|}{ Sums of squares } \\
\hline & & \multicolumn{2}{|c|}{ Head wt } & \multirow{2}{*}{$\begin{array}{c}\text { CR } \\
\text { severitv }\end{array}$} & \multicolumn{2}{|c|}{ Root dry wt } \\
\hline & & Fresh & Marketable & & Tap & Lateral \\
\hline Location (Loc.) & 4 & $4,785,694^{* *}$ & $2,792,893^{* *}$ & $944.1^{* *}$ & $172.4^{* *}$ & $0.12^{* *}$ \\
\hline Replications (Loc.) & 35 & $250,901^{\mathrm{NS}}$ & $212,386^{* *}$ & $28.7^{\mathrm{NS}}$ & $7.2^{\mathrm{NS}}$ & $0.05^{\mathrm{NS}}$ \\
\hline Cultivars & 3 & $108,721^{* *}$ & $853,101^{* *}$ & $327.6^{* *}$ & $39.6 * *$ & $0.26^{* *}$ \\
\hline Loc. \& cultivars & 12 & $2,305,126^{* *}$ & $1,809,360^{* *}$ & $216.9^{* *}$ & $84.4^{* *}$ & $0.15^{* *}$ \\
\hline Error & 105 & 549,002 & 316,089 & 57.1 & 23.9 & 0.13 \\
\hline \multicolumn{7}{|l|}{ Contrast estimates } \\
\hline Loc. A \& B vs. D \& E & & $415.3^{* *}$ & $320.4^{* *}$ & $1,011 * *$ & $156.3^{* *}$ & $45.0^{* *}$ \\
\hline Loc. A \& B vs. C & & $247.2^{* *}$ & $111.1^{* *}$ & $566.4^{* *}$ & $442.4^{* *}$ & $14.4^{* *}$ \\
\hline Loc. C vs. D \& E & & NS & $16.6^{* *}$ & $4.7^{*}$ & $117.2 * *$ & $85.9^{* *}$ \\
\hline Cultivar 1 \& 2 vs. $3 \& 4$ & & $193.9^{* *}$ & $274.3^{* *}$ & $598.7^{* *}$ & $166.6^{* *}$ & $222.8^{* *}$ \\
\hline Cultivar 1 vs. 2 & & NS & NS & NS & $7.6^{* *}$ & $4.1 * *$ \\
\hline Cultivar 3 vs. 4 & & $11.8^{* *}$ & $9.1^{* *}$ & NS & NS & NS \\
\hline
\end{tabular}

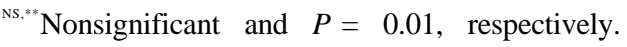
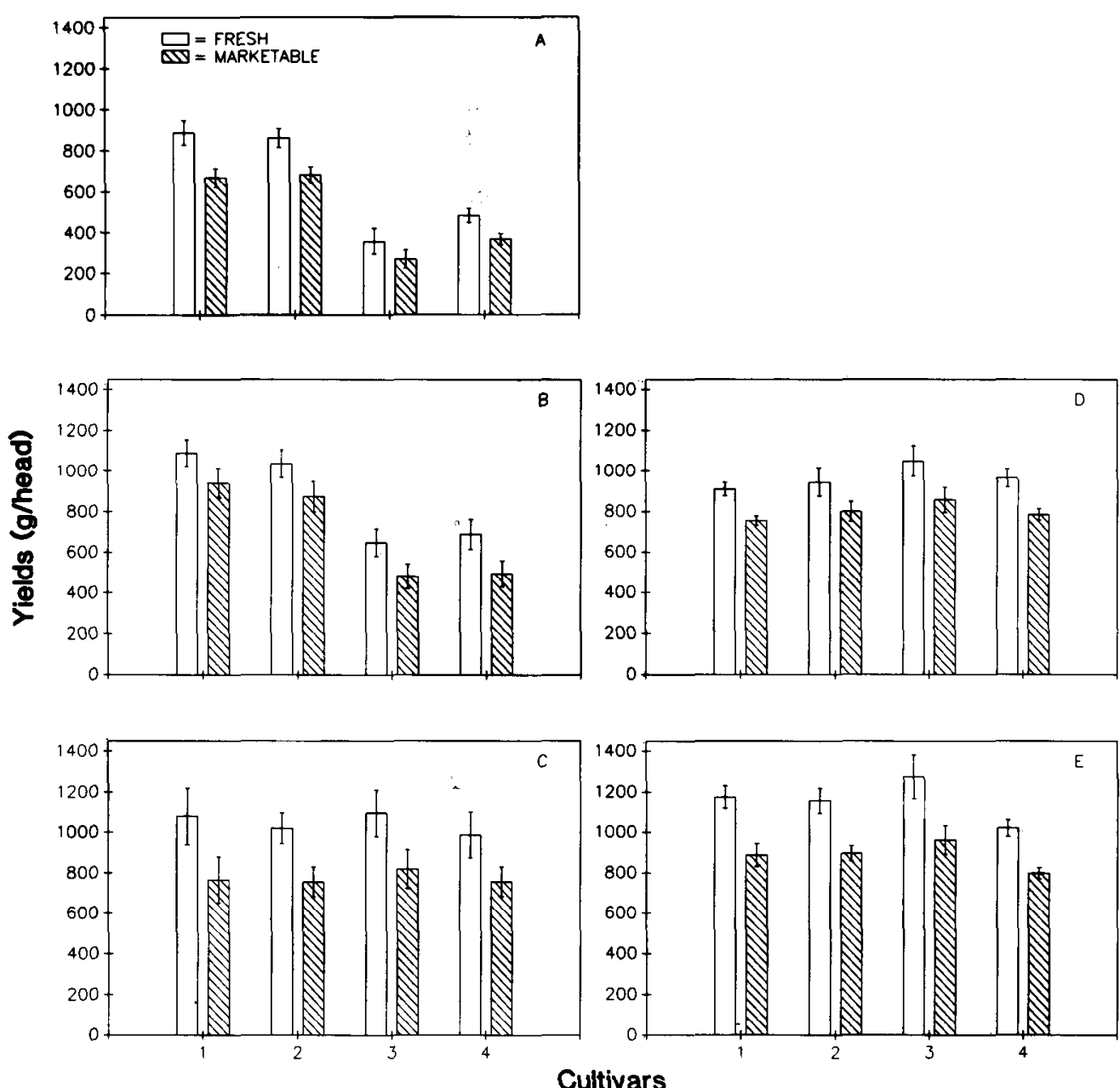

Fig. 1. Fresh and marketable yields (grams per head) of CR-resistant, $1=$ Raleigh and 2 = South Bay, and susceptible, $3=$ Ithaca and 4 = Shawnee, crisphead lettuce at five Florida locations. Locations A and B = fields cropped to continuous lettuce for six seasons, Location $\mathrm{C}=$ fields cropped to continuous lettuce for three seasons; Locations $\mathrm{D}$ and $\mathrm{E}=$ first time ever planted to lettuce, previously planted to sugarcane for 20 years. Vertical bars represent standard deviations.

more, 1988) ranging from 1 to 9 . The modification was made to adapt the scale to field-grown plants where $1=$ no discoloration of tap root to $9=$ dark brown discoloration and/or partial disintegration of taproot, longitudinal cracks penetrating well into cortex $\geq 10 \mathrm{~mm}$. Isolations of $R$. suberifaciens were made from yellow or corked areas on the roots as described by van Bruggen et al. (1988). Briefly, each root was washed, placed in $20 \mathrm{ml}$ of distilled water, and sonicated for $20 \mathrm{~min}$. Root extracts were filtered through a $0.650-\mu \mathrm{m}$ Millipore filter, and $0.01 \mathrm{ml}$ of filtrate was plated on S-medium plus $30 \mathrm{mg}$ strep- 

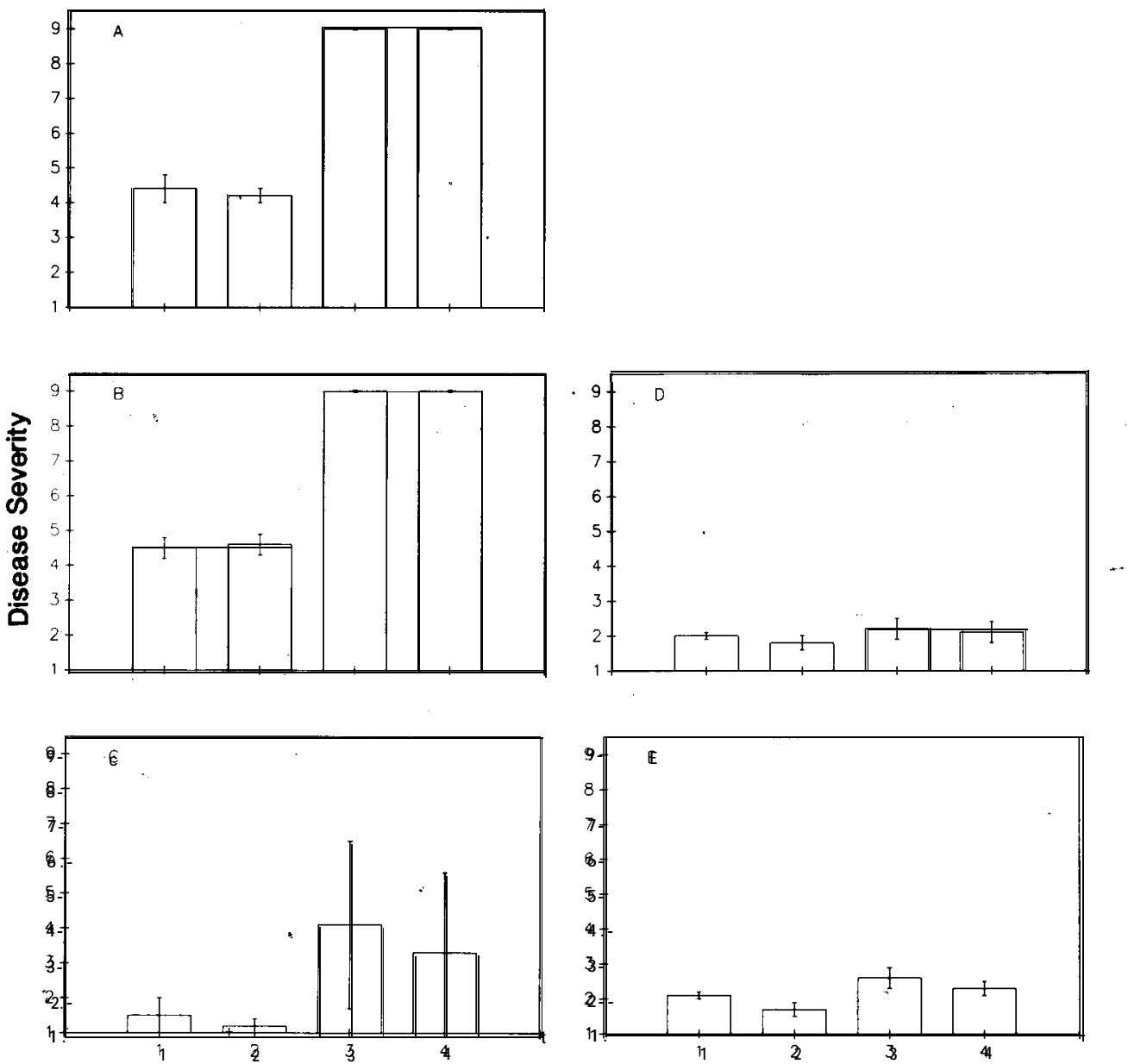

Cultivars

Fig. 2. Disease severity $(i=$ no disease and $\overline{9}=$ completely diseased $)$ of CR-resistant, $1=$ Raleigh and $2=$ South Bay, and -susceptible, 3 = Ithaca and $4=$ Shawnee, crisphead lettuce at five Florida locations. Locations A and B $=$ fields cropped to continuous lettuce for six seasons, Location $\mathrm{C}=$ field cropped to continuous lettuce for three seasons; Locations $\mathrm{D}$ and $\mathrm{E}=$ first time ever planted to lettuce, previously planted to sugarcane for 20 years. Vertical bars represent SD.

Table 2. Correlation coefficients for CR severity and head and root weights of lettuce grown at five locations.

\begin{tabular}{lccccc}
\hline \hline \multirow{2}{*}{$\begin{array}{c}\text { CR } \\
\text { severity } \\
\text { and location }\end{array}$} & \multicolumn{2}{c}{ Head wt } & & \multicolumn{2}{c}{ Root dry wt } \\
\cline { 2 - 3 } \cline { 5 - 6 } \cline { 5 - 6 } Shole & Marketable & & Tap & Lateral \\
\hline Severe (A) & $-0.95^{* * *}$ & $-0.95^{* * *}$ & & $-0.92^{* * *}$ & $-0.88^{* * *}$ \\
Severe (B) & $-0.95^{* * *}$ & $-0.95^{* * *}$ & &..$-^{x}$ &.-- \\
Moderate (C) & NS & NS & & $-0.39^{*}$ & $-0.54^{* *}$ \\
Low (D) & --- & NS & & NS & NS \\
Low (E) & NS & NS & & $-0.38^{*}$ & $-0.38^{*}$ \\
\hline
\end{tabular}

${ }^{z}$ Marketable $=$ head weight - wrapper leaves.

"Locations $\mathrm{A}$ and $\mathrm{B}=$ fields cropped to continuous lettuce for six seasons, Location $\mathrm{C}=$ field cropped to continuous lettuce for three seasons; Locations $\mathrm{D}$ and $\mathrm{E}=$ first time ever planted to lettuce, previously cropped to sugarcane for 20 years.

${ }^{x}$ Not included.

NS $* * * * * *$ Nonsignificant or significant at $P<0.01,0.001,0.0001$, respectively.

tomycin sulfate. Afterward, plates were incubated at $28 \mathrm{C}$ for 2 to 3 weeks. Dry weights of the tap and lateral roots also were recorded, except at Location B. Tap and lateral roots were not separated from each other at this location and were not included in the data analysis. All field experiments were analyzed as a factorial design arranged in a randomized complete block. Factors included locations and cultivars. Statistical computations were made using software provided by Statistical Analysis Systems (release 6.03, SAS Institute, Cary, N.C.). The SAS general linear models procedure was used to perform analysis of variance (ANOVA), followed by a series of single-degree-offreedom contrasts (Gomez and Gomez, 1984).

\section{Results and Discussion}

A significant location $\times$ cultivar interaction was present $(\mathrm{Ta}-$ ble 1). This interaction was expected, since the locations differed in lettuce cropping histories and degree of CR intensity. Differences also were found and expected between the CR-resistant and -susceptible cultivars.

Based on the SD about the means, yields of resistant and susceptible cultivars generally were not different in fields cropped to lettuce for the first time at locations D and E (Fig. 1). The yield potentials of the CR-resistant and CR-susceptible cultivars used in these tests appear to be similar in the absence of CR. There was no difference in CR severity among cultivars at Locations $\mathrm{D}$ and $\mathrm{E}$, with average severity ratings of $\approx 2$ (Fig. 2). Although CR symptoms were recorded on the susceptible cultivars at Location C (Fig. 2), there were no differences in yield between resistant and susceptible cultivars (Fig. 1). 


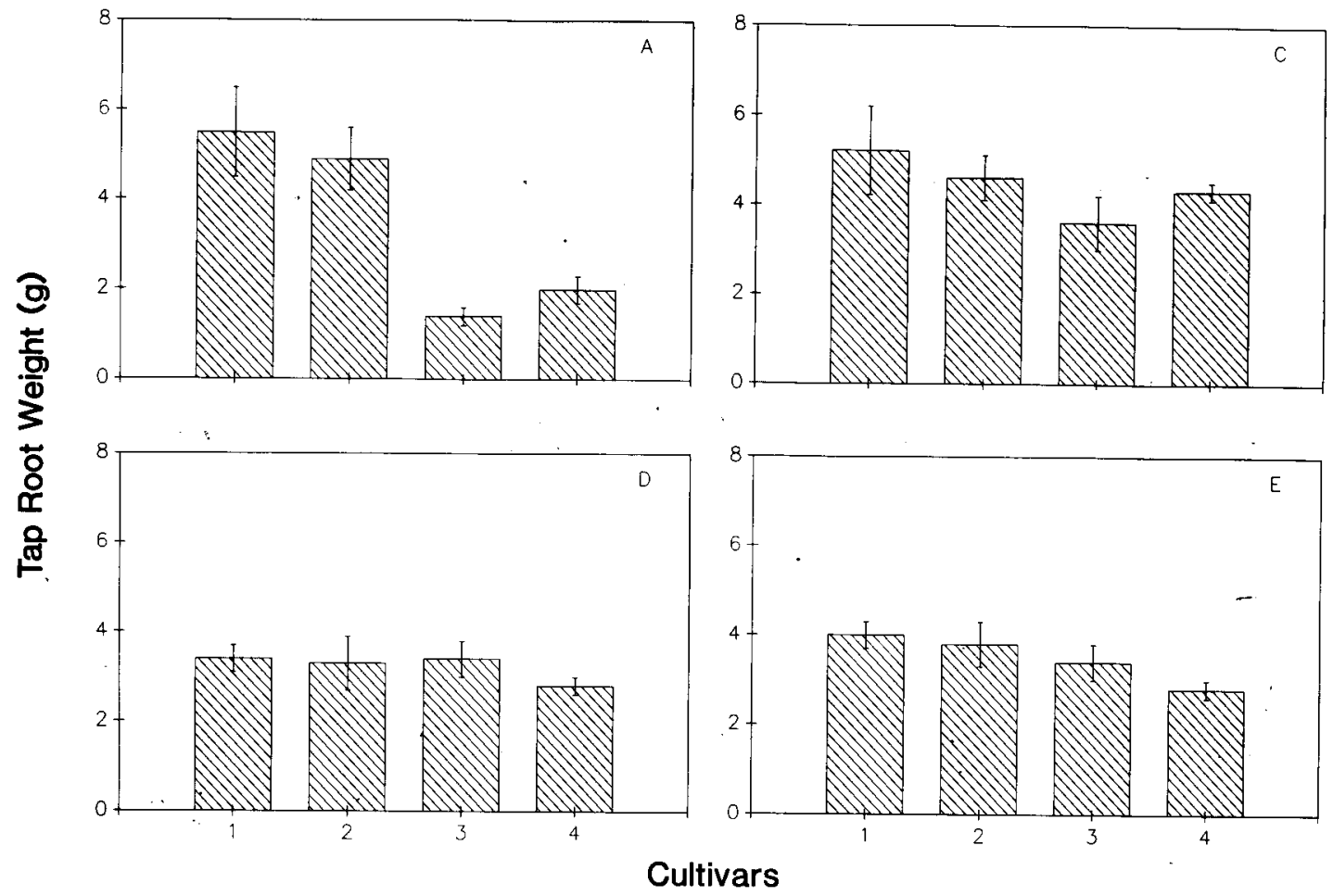

Fig. 3. Dry tap root weights (grams per root) of CR-resistant, $1=$ Raleigh and $2=$ South Bay and -susceptible, $3=$ Ithaca and $4=$ Shawnee, crisphead lettuce at four Florida locations. Location $\mathrm{A}=$ field cropped to continuous lettuce for six seasons, Location $\mathrm{C}=$ field cropped to continuous lettuce for three seasons; Locations D and E = first time ever planted to lettuce, previously planted to sugarcane for 20 years.. Vertical bars represent SD.

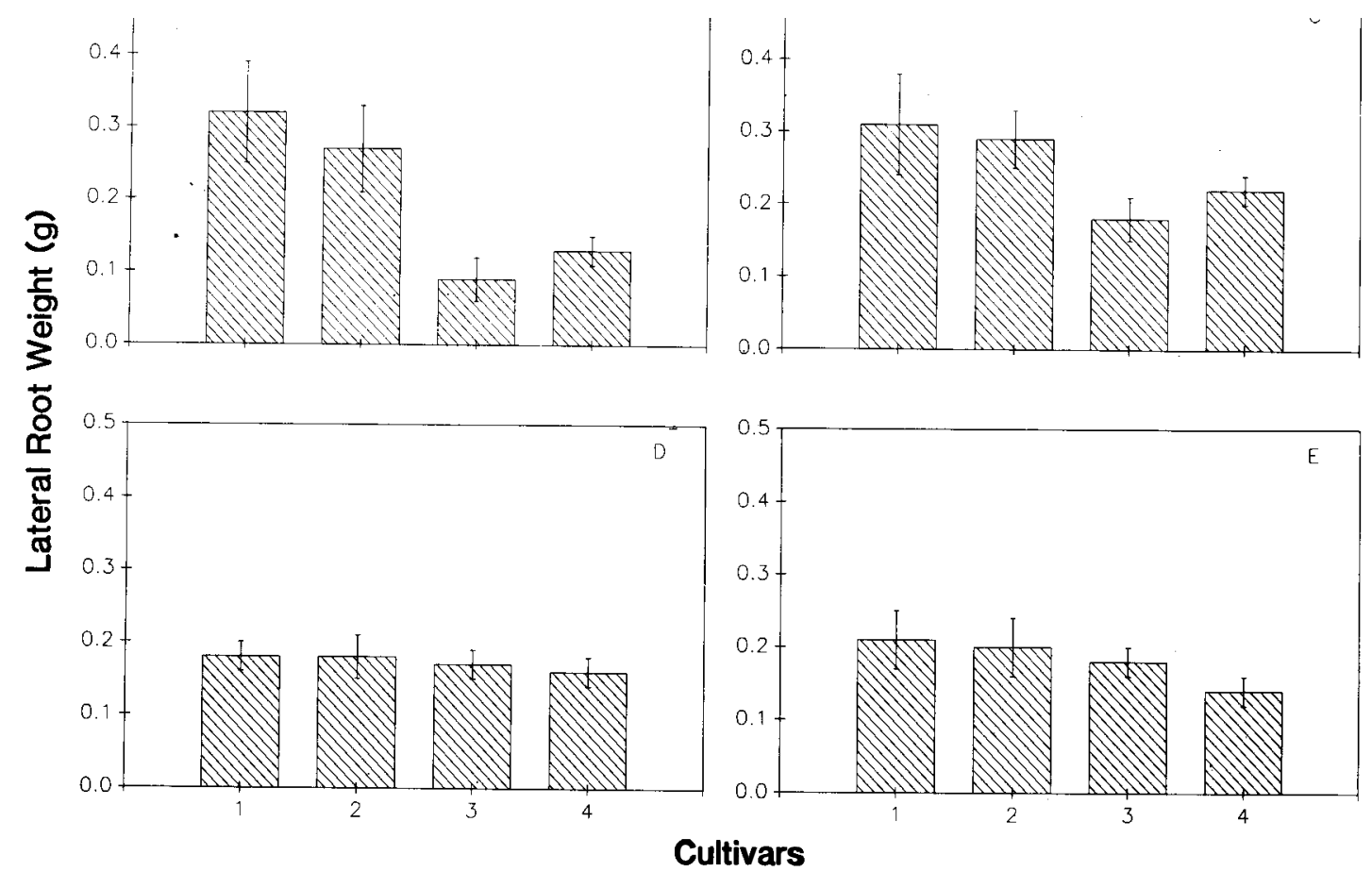

Fig. 4. Dry lateral root weights (grams per root) of CR-resistant, $1=$ Raleigh and $2=$ South Bay, and - susceptible, $3=$ Ithaca and $4=$ Shawnee, crisphead lettuce cultivars at four Florida locations. Location A = field cropped to continuous lettuce for six seasons, Location C = field cropped to continuous lettuce for three seasons; Locations $\mathrm{D}$ and $\mathrm{E}=$ first time ever planted to lettuce, previously planted to sugarcane for 20 years. Vertical bars represent SD.

Yield losses possibly could occur in resistant cultivars. However, the yields of the resistant cultivars grown in heavily in- fested fields of $\mathrm{CR}(\mathrm{A}$ and $\mathrm{B})$ were equal to those grown in fields with no previous history of lettuce production (D and $\mathrm{E})$ 
(Fig. 1). Data reported herein are in agreement with similar observations in California where no yield reductions were observed for a CR-resistant breeding line when comparing yields from microplots infested with $R$. suberifaciens and noninfested plots (O'Brien and van Bruggen, 1989b). Apparently, for severity ratings of $\leq 4$, CR did not result in significant yield reductions.

Yields were reduced in the susceptible cultivars by $37 \%$ and $46 \%$ at Location A, and 52\% and 53\% at Location B for fresh and marketable weights, respectively (Fig. 1). These yield losses are similar to those reported by O'Brien and van Bruggen (1989a) although soils, climate, and lettuce types were different. Since CR has been reported to occur on mineral and highly organic soils, soil type appears to have little effect on disease development.

Although the $\mathrm{pH}$ of the soils in this study varied, it is doubtful this had any effect on CR development. $R$. suberifaciens has been reported to grow at $\mathrm{pH}$ values from 5.7 to 8.2 in vitro (Van Bruggen et al., 1990).

There was a high negative correlation between lettuce head weight and CR severity (Table 2). In addition, CR severity was negatively correlated with dry root weight. Tap and lateral dry root weights of CR-susceptible cultivars were significantly lower than those of the resistant cultivars in a heavily infested field, Location A (Figs. 3 and 4). van Bruggen et al. (1989) found that the dry weights of tap roots infected by $R$. suberifaciens increased, while our observations were the opposite. Since some heavily infected roots were partially disintegrated in our experiment, this might explain the observed differences. Although the negative impact of CR on lateral root formation has been reported, this represents the first quantitative data on lateral root disintegration by $R$. suberifaciens. This information could prove useful when screening breeding lines or cultivars for tolerance to this disease, especially if the breeding material tended to produce numerous lateral roots. Only the lateral root dry weights of the susceptible cultivars were significantly reduced in comparison to the resistant cultivars in a moderately infested field, Location C (Fig. 4).

R. suberifaciens was isolated from yellow or slightly corked areas (severity ratings of 2 to 4 ) of the roots at Locations D and $\mathrm{E}$, although the rate of recovery was low. It is possible that toxins produced by the bacterium could have been causing the milder CR symptoms (ratings of 2 to 4); consequently, the bacterium would not have been isolated from root tissue (Kao et al., 1984).

The pathogen was not isolated from severely infected roots, possibly because the bacterium was overgrown by secondary invaders. $R$. suberifaciens is probably endemic to the organic soils of Florida, possibly surviving in association with the rhizosphere of various crop and weed species (Leben, 1981). Similar observations were made on lettuce grown in soil recently brought into production after pasture or forest (van Bruggen et al., 1990a). $R$. suberifaciens also has been isolated from a variety of field-grown crops and demonstrated to be pathogenic on lettuce (van Bruggen et al., 1990a).

This is the first quantitative information on the impact of CR disease on yields of lettuce in Florida. Based on this information and current lettuce production practices, host resistance will continue to be the best method for controlling this disease. However, the stability of this resistance is unknown. Consequently, more information on the epidemiology of this disease needs to be investigated. For example, lettuce is usually rotated with sugarcane in Florida. After several cropping cycles of lettuce, fields become heavily infested with CR. Temporal studies on CR severity under lettuce monoculture need to be conducted. From this information, various characteristics of the epidemic occurring in the field could be discerned, such as the time of disease onset, initial amount of disease, rate of the disease increase, etc. This information would be invaluable for evaluating other potential control strategies for disease management.

\section{Literature Cited}

Brown, P.R. and R.W. Michelmore. 1988. The genetics of corky root resistance in lettuce. Phytopathology 78: 1145-1 150.

Busch, L.V. and G.L. Barren. 1963. Root rot of head lettuce in Ontario. Can. J. Plant Sci. 43:166-173.

Datnoff, L.E. and R.T. Nagata. 1990. Isolation. of Rhizomonas suberifaciens in Florida. Plant Dis. 74:394.

D'Ercole, N. 1981. La suberosi radicale dells lattuga. Terra Vita 41:4041.

Gomez, K.A. and A.A. Gomez. 1984. Statistical procedures for agricultural research. Wiley, New York.

Guzman, V.L. 1981. Yield and quality response of crisphead lettuce cultivars to seeding dates and farms in south Florida organic soils. Proc. Fla. State Hort. Soc. 94:182-185.

Guzman, V.L. 1984. South Bay and Raleigh, two crisphead lettuce cultivars resistant to corky root rot for organic soils. Fla. Agr. Expt. Stat. Circ. S-310.

Guzman, V.L. 1986. Short Guzmaine, Tall Guzmaine and Floriglade, three cos lettuce cultivars resistant to lettuce mosaic virus. Fla. Agr. Expt. Sta. Circ. S-326.

Guzman, V. L., T.A. Zitter, and D.D. Gull, 1990. FloriCal 48060 and FloriCal 50011, two western type crisphead lettuce cultivars tolerant to lettuce mosaic virus. Fla. Agr. Expt. Sta. Circ. S-366.

Kao, J., D.H. Mitten, and C.A. Milich. 1984. Identification of a hostspecific toxin produced by the corky root rot bacterial pathogen of lettuce. Phytopathology 74:844.

Leben, C. 1981. How plant-pathogenic bacteria survive. Plant Dis, 65:633-637.

O'Brien, R.D. and A.H.C. van Bruggen. 1989a. Disease losses to California-type resistant and susceptible iceberg lettuce cultivars caused by infectious corky root. Phytopathology 79:910-911.

O'Brien, R.D. and A.H.C. van Bruggen. 1989b. Interaction between corky root bacteria and susceptible and resistant lettuce cultivars. California Iceberg Lettuce Res. Program Annu. Rpt., 1 Apr, 198931 Mar. 1990. p. 44-45.

Pataky, J.K. and S.M: Lim. 1981. Effects of row width and plant growth habit on Septoria brown spot development and soybean yield. Phytopathology 71:1051-1056.

van Bruggen, A. H. C., R.G. Grogan, C.P. Bogdanoff, and C.M. Waters. 1988. Corky root of lettuce in California caused by a gram-negative bacterium. Phytopathology 78:1139-1145.

van Bruggen, A. H. C., P.R. Brown, and K.N. Jochimsen. 1989. Corky root of lettuce caused by strains of a gram-negative bacterium from muck soils of Florida, New York, and Wisconsin. Applied and Environ. Microbiol. 55:2635-2640.

van Bruggen, A. H. C., P.R. Brown, and K.N. Jochimsen. 1990a. Host range of Rhizomonas suberifaciens, the causal agent of corky root of lettuce. Plant Dis. 74:531-584.

van Bruggen, A. H. C., K.N. Jochimsen, and P.R. Brown. 1990b. Rhizomonas suberifaciens gen. nov., sp. nov., the causal agent of corky root of lettuce. Intl. J. Syst. Bacteriol. 40:175-188.

Waters, C. M., and R.G. Grogan. 1984. Identification of the bacterium causing lettuce corky root. Phytopathology 74:857. 